\title{
STOSOWANIE LOGIKI W FILOZOFII. O DYSKUSJI MIĘDZY STANISŁAWEM KAMIŃSKIM I JANEM F. DREWNOWSKIM
}

\begin{abstract}
Abstrakt. Artykuł prezentuje i komentuje dyskusję pomiędzy J. F. Drewnowskim a S. Kamińskim, której przedmiotem było stosowanie logiki w filozofii, a ściślej w metafizyce ogólnej o orientacji arystotelesowsko-tomistycznej. Drewnowski prezentował w niej stanowisko reprezentatywne dla tzw. Koła Krakowskiego o możliwości stosowania narzędzi logiki formalnej w metafizyce, Kamiński takiej możliwości zaprzeczał. Spróbujemy wskazać pewne wnioski z tej dyskusji przydatne dla dzisiejszego rozumienia stosowania (stosowalności) logiki w filozofii. W końcowej partii podjęta jest próba znalezienia przyczyn stanowiska Kamińskiego, które jest reprezentatywne dla przedstawicieli tzw. lubelskiej szkoły filozoficznej.
\end{abstract}

Słowa kluczowe: stosowalność logiki, metafizyka tomistyczna, system metafizyki klasycznej, formalizacja dowodu ex motu

1. Krótka historia dyskusji. 2. Kwestie sporne. 3. Swoistość metafizyki. 4. Horror logisticus.

W początku lat sześćdziesiątych miała miejsce dyskusja epistolograficzna i publikacyjna (nigdy bezpośrednia) dotycząca stosowania logiki formalnej (zwanej wówczas matematyczną czy logistyką) pomiędzy Janem F. Drewnowskim a Stanisławem Kamińskim. Obie strony przywoływały liczne argumenty za i przeciw, przy czym w tle dyskusji można znaleźć odwołanie do największego przedwojennego osiągnięcia tzw. Koła Krakowskiego, a mianowicie Salamuchy formalizacji dowodu ex motu Arystotelesa i, pośrednio, do całego programu Koła Krakowskiego. W niniejszej pracy przedstawimy w zarysie dyskusję Drewnowski - Kamiński, a następnie spróbujemy wskazać pewne wnioski z tej dyskusji przydatne dla dzisiejszego rozumienia stosowania (stosowalności) logiki w filozofii. 


\section{KRÓTKA HISTORIA DYSKUSJI}

Ponieważ dokładnie dyskusję między Drewnowskim a Kamińskim (i Zdybicką) przedstawia M. Adamczyk ${ }^{1}$, nie ma potrzeby powtarzać tu całego jej przebiegu. Ograniczymy się jedynie do przypomnienia jej głównych etapów i punktów będących przedmiotem sporu.

Jak można się domyślić z korespondencji Drewnowskiego, głównym asumptem do dyskusji był artykuł Kamińskiego Logika wspótczesna a filozofia ${ }^{2}$. Wodpowiedzi na ten artykuł Kamińskiego Drewnowski napisał pracę Czy możliwe jest stosowanie logiki symbolicznej w metafizyce ${ }^{3}$. Kolejny element dyskusji to maszynopis pracy Kamińskiego Co daje stosowanie logiki symbolicznej do metafizyki

1 Por. M. Adamczyk, Wiedza - wiara - racjonalność. Jana Franciszka Drewnowskiego program logizującej modernizacji myśli filozoficzno-teologicznej, Lublin 2015, 271-301.

2 S. Kamiński, Logika współczesna a filozofia, Roczniki Filozoficzne 9(1961)1, 49-84. Drewnowski w liście do Kamińskiego z dn. 9.XI. 1962 r. pisał: „w międzyczasie przeczytałem w Znaku nr 97-98 recenzję z prac Przew. Księdza drukowanych w Rocznikach Filozoficznych. Zaniepokoiło mnie to, co tam napisano o »zaprzepaszczeniu swoistości filozofi« przez ks. Salamuchę i o. Bocheńskiego. Kupiłem więc egzemplarz Roczników, tom IX, zesz. 1, by zapoznać się z pracą Przew. Księdza pt. Logika a filozofia. Jeżeli dobrze zrozumiałem, to nie ze wszystkim mógłbym się zgodzić (...) Zapytuję więc uprzejmie, czy Przew. Ksiądz zechciałby przeprowadzić ze mną dyskusję na temat tych punktów Jego pracy, które budzą moje wątpliwości" (mps 1.322 (1.3)a). W cytowanym liście mowa jest o recenzji napisanej przez Stróżewskiego, w której autor pisze: „Jeśli chodzi o rezultaty stosowania logiki współczesnej do tradycyjnie pojętej filozofii, zwłaszcza metafizyki, to trzeba stwierdzić, że nie są one zadowalające. Więcej, bardzo często prowadziły do zatarcia czy wręcz zaprzepaszczenia swoistości filozofii”; por. W. Stróżewski, Wśród publikacji filozoficznych, Roczniki Filozoficzne, Znak 97-98(1962)7-8, 1258-1263; swoją drogą aż tak ostre słowa w artykule Kamińskiego nie padają.

3 Mps datowany na maj czerwiec 1963 r (oznaczony jako 1.322 (1.3)b). Skrócona wersja tego artykułu, uwzględniająca już pracę Kamińskiego Co daje stosowanie ukazała się w roku 1965; por. J.F. Drewnowski, Stosowanie logiki symbolicznej w filozofii, Studia Philosophiae Christianae 1-2(1965), 53-65; w wersji drukowanej pominięto w szczególności: obszerny początkowy cytat z Łukasiewicza z jego Elementów dotyczący logiki formalnej i filozoficznej, uwagi o rozumieniu implikacji, uwagi o rozszerzeniach klasycznego rachunku logicznego. 
wspótczesnej ${ }^{4}$. $W$ odpowiedzi na maszynopis Kamińskiego Drewnowski (10 lutego 1964 r.) przesłał do Kamińskiego list z uwagami komentarzami ${ }^{5}$ do pracy Co daje stosowanie logiki symbolicznej do metafizyki wspótczesnej. List ten wrócił do Drewnowskiego z dopiskami na marginesie (czasem dość silnie polemicznymi) skomentowanymi przez Drewnowskiego w Uwagach do marginesowych dopisków ${ }^{6}$. Dalszy etap dyskusji to publikacja przez Drewnowskiego w Znaku tekstu Uwagi w zwiqzku z artykutem dyskusyjnym ks. Stanistawa Kamińskiego i s. Zofii J. Zdybickiej pt. „O sposobie poznania istnienia Boga”, Znak 128-129(1965)2-3, 346-355 i praca Kamińskiego i Zdybickiej Wodpowiedzi na uwagi Jana Fr. Drewnowskiego ${ }^{7}$, która, jak się wydaje, dyskusję tę kończy. Ogólnie odnosi się wrażenie, że Drewnowski w żadnym momencie nie czuje się zrozumiany i, zakładając dobrą wolę dyskutantów, zdaje się, że rzecz ad principiam venit.

\section{KWESTIE SPORNE}

Listę kwestii spornych w dyskusji można przedstawić w zarysie, za Adamczykiem, jak następuje:

4 Mps 1.322 (1.3) c; drukiem wydany jako Co daje stosowanie logiki formalnej do metafizyki klasycznej, Roczniki Filozoficzne 12(1964)1, 107-112 (przedruk w S. Kamiński, Jak filozofować, red. T. Szubka, Lublin 1989, 124-134.

5 Mps 1.322 (1.3) d, stron 5, kończący się słowami „będę czekał na wiadomość od Ks. Profesora i w międzyczasie będę próbował na własną rękę formułować te wspólne konkluzje w założeniu, że Ks. Profesor uznaje słuszność obecnych mych zastrzeżeń".

6 Mps nr 1.322 (1.3) e; w uwagach Drewnowski wskazuje na liczne nieporozumienia czy też niezrozumienie ze strony Kamińskiego, kończąc pesymistycznie: „Zwrócenie mego maszynopisu świadczy, że ks. K. tymi sprawami w ogóle nie interesuje się i że nie chce o nich dalej dyskutować. Potwierdza to zaś skwapliwe drukowanie własnej odpowiedzi na mój pierwszy maszynopis, pomimo iż wysunąłem do niej tyle zastrzeżeń. Znowu więc nie dopuszczam myśli, żeby tu miało miejsce umyślne pomijanie moich argumentów, które się rozumie, ale których się nie chce przyjąć do wiadomości, ponieważ są niewygodne. Pozostaje więc tylko wniosek, iż moje argumenty nie są zrozumiałe”.

7 S. Kamiński, Z.J. Zdybicka, W odpowiedzi na uwagi Jana Rf. Drewnowskiego, Znak 128-129(1965)2-3, 355-365. 
a. stosowanie logiki do innych nauk;

b. problem stosunku implikacji;

c. wynikanie logiczne a metafizyczne;

d. ekstensjonalność KRL;

e. rozszerzenia KRL;

f. krytyka zastosowań logiki do metafizyki;

g. zarzuty pod adresem pracy Salamuchy

h. problem aksjomatyzacji metafizyki;

i. problem uzasadniania w metafizyce;

j. logiczno-formalne kryterium metafizyki.

Ad a) Punktem wyjścia autorów jest twierdzenie, że klasyczny rachunek logiczny jest podstawą zastosowania logiki w innych dziedzinach wiedzy. Według Drewnowskiego stosować należy metodę Hilberta i Ackermanna, co oznacza, że „ustala się nowe symbole stałe, wyrażające swoiste pojęcia danej dziedziny, i opisuje się rodzaju przedmiotów oznaczanych przez argumenty tych nowych symboli funkcyjnych. Za pomoca tych symboli i symboli rachunku funkcyjnego podaje się symboliczne sformułowanie przesłanek danej dziedziny", które dołącza się do aksjomatów rachunku funkcyjnego jako nowe aksjomaty. Ważne jest, że nie dokonuje się przekładu na symbole KRL (one zachowują swoje znaczenie), podczas gdy nowe symbole mają swoiste znaczenie. Próba zaksjomatyzowania całej dziedziny wymaga doboru symboli swoistych zapewniającego adekwatne definicje pojęć dziedziny. Takie próby nie są też interpretowaniem symboli rachunku logicznego, jako że pozostają one ze zmiany znaczenia (zachowuje się znaczenie w KRL) ${ }^{8}$ Z kolei Kamiński wskazuje dwie możliwe metody stosowania logiki w metafizyce:

- interpretację ontologiczną fragmentów logiki nazw, która jest, jego zdaniem, nieciekawa';

8 Por. J.F. Drewnowski, Czy możliwe jest stosowanie logiki symbolicznej w metafizyce?, dz. cyt., 5.

9 S. Kamiński, Logika współczesna a filozofia, dz. cyt., 68. 
- transponowanie zdań metafizyki na symboliczny język logiki, które prowadzi do przedstawienia fragmentu metafizyki w postaci fragmentu systemu dedukcyjnego; takie działania Kamiński przypisuje właśnie próbom Salamuchy i Bocheńskiego. Drewnowski stanowczo protestuje w tej kwestii podkreślając fakt, iż symbole stałe metafizyki zachowują swoje znaczenie, a symbole rachunku z kolei zachowują swoje zwykłe znaczenie logiczne ${ }^{10}$.

Ad b) Według Drewnowskiego rozpowszechniony bywa pogląd, że pojęcie implikacji materialnej stosowalne jest jedynie w matematyce; wbrew temu wskazuje on na fakt, że dyskusje nad implikacją toczone były już w starożytności (w kontekstach filozoficznych) i stąd można uznać implikację za uniwersalny stosunek międzyzdaniowy. W tej kwestii Kamiński wskazuje, iż nie ma on zastrzeżeń do samej implikacji materialnej, natomiast problematyczna jest teza, że wyraża ona wystarczająco wszelkie konieczne związki między tezami metafizyki klasycznej ${ }^{11}$.

Ad c) $\mathrm{Z}$ tą kwestią bezpośrednio jest powiązane rozumienie wynikania. Według Kamińskiego „nie można się dopatrzyć potrzebnej izomorfii między wynikaniem logicznym a wynikaniem zachodzącym w systemie filozofii bytu. Logika ma zastosowanie przy wyprowadzaniu konkluzji nie będących prawami logicznymi z przesłanek również nie stanowiących prawd logicznych. Zachodzi to jedynie gdy zdanie o spójniku »Jeżeli... to... ł łączy przesłanki z konkluzją oraz jest logicznie (zależy od samej formy) prawdziwe. Tymczasem zasadnicze tezy metafizyki łączą się nie tylko na podstawie formy"12; innymi

10 Drewnowski, Czy możliwe jest stosowanie logiki symbolicznej w metafizyce?, dz. cyt., 5.

11 Oczywiście Drewnowski tak nie twierdzi. Sama kwestia implikacji materialnej jest oczywiście trudna; w logice zdefiniowano wiele funktorów implikacji celem zbliżenia znaczenia tych funktorów do znaczenia równych użyć okresu warunkowego języka naturalnego do wyrażania np. związków kauzalnych, następstwa czasowego, wynikania, inferencji zbliżonej do potocznej, okresów kontrfaktycznych właściwych prawom nauki, etc.

12 Por. S. Kamiński, Logika współczesna a filozofia, dz. cyt., 75. 
słowy, Kamińskiemu chodzi o podkreślenie związków treściowych w metafizyce. W odpowiedzi Drewnowski zauważa, że metafizyka $\mathrm{w}$ tym aspekcie nie różni się od jakiejkolwiek innej dziedziny nauki - każda teoria to powiązany logicznie i treściowo zbiór twierdzeń; skoro inne dziedziny dają się zaksjomatyzować, a ich rozumowania - sformalizować, a rozumowania metafizyki takim zabiegom miałyby się nie poddawać, to metafizyka nie zasługiwałaby na miano nauki ${ }^{13}$. W dodatku do tego, w Odpowiedziach Kamiński i Zdybicka podkreślali, że KRL nie stanowi kodyfikacji każdego rozumowania ważnego (a wynikanie 'czysto formalne' nie jest jedyną podstawą uzasadniania twierdzeń), natomiast możliwa jest ' jakaś logika treści'14. „Skoro metafizyka jest wiedzą o egzystencjalnej stronie rzeczywistości, a więc jest nauką realną, specyficznie ujmującą istnienie - to nie wolno w niej ograniczać się do uzasadnień, które nie brałyby pod uwagę swoiście i bezpośrednio ujętego stanu rzeczy w świecie pozajęzykowym, lecz zamykałyby się wewnątrz systemu językowego, czyli w ramach nieempirycznych reguł języka. W metafizyce trzeba koniecznie uwzględnić przede wszystkim bezpośrednie kontakty poznawcze z rzeczywistością. Tylko one umożliwiają ujęcie jej $\mathrm{w}$ aspekcie istnienia i związków ze względu na istnienie. Dlatego też w rozumowaniach nie może się obejść bez intelektualnej percepcji relacji między „treściami” i „istnieniem bezpośrednio ujętym” ${ }^{15}$.

13 Por. J.F. Drewnowski, Czy możliwe jest stosowanie logiki symbolicznej w metafizyce?, dz. cyt., 16-18.

14 Ciekawe jest, że Kamiński najprawdopodobniej nie brał poważnie rozwijających się wówczas prężnie wielu odmian logik 'filozoficznych'; jest to ciekawe, jako że musiał on znać np. Priora logiki tensalne czy różne rodzaje logik modalnych. Owe logiki nieklasyczne proponowały wszak nowe rodzaje funktorów i nowe rodzaje operacji inferencji. Wygląda na to, że Kamiński tak naprawdę nie wyszedł w swoim myśleniu poza klasyczny rachunek zdań i teorię zdań kategorycznych, nie ma w jego pracach zasadniczo nawet prób stosowania węższego rachunku predykatów czy bardzo filozoficznej ontologii Leśniewskiego.

15 Por. S. Kamiński, Z.J. Zdybicka, W odpowiedzi, dz. cyt., 210. Nawiasem mówiąc, autorzy ci zdają się mieszać różne porządki: co innego jest ujęcie intuitywne relacji w bycie, intelektualna percepcja istnienia etc., a czym innym wyrażenie tych danych w zdaniach 
Ad d) Kolejna kwestia to sprawa rozumienia ekstensjonalności. Kamiński podkreślał, w kontekście niemożności adekwatnego stosowania logiki do formalizacji metafizyki ${ }^{16}, \dot{z} e$,przekładanie wyrażeń metafizyki na język logiki byłoby uprawnione jedynie wówczas, gdyby oba języki były izomorficzne. Tymczasem logika współczesna jest ekstensjonalistyczna, zbudowana jedynie $\mathrm{z}$ funktorów zakresowych i symboli zmiennych. Natomiast język filozofii bytu nie tylko jest treściowy, ale specyficznie treściowy (analogia)"17. Te uwagi doprowadziły Drewnowskiego do wyróżnienia różnych rodzajów ekstensjonalności, a mianowicie trzech znaczeń terminu ekstensjonalność:

- ekstensjonalność KRL ze względu na równoważność; takie znaczenie terminu jest wyznaczone przez regułę zastępowania członów równoważności. Drewnowski wskazywał, zupełnie słusznie, że na gruncie KRL nie jest możliwa zastępowalność dla funktorów dzisiaj nazywanych intensjonalnymi (np. epistemicznych, używanych do wyrażania oratio obliqua). Dla takich funktorów trzeba stosować rozszerzenia KRL;

- ekstensjonalność KRL ze względu na tożsamość: ponieważ znak identyczności nie należy do KRL, tak rozumiana ekstensjonalność dotyczy rozszerzeń KRL przez wprowadzenie reguły zastępowania członów identyczności.

Te dwa rozumienia ekstensjonalności nie budzą zastrzeżeń Drewnowskiego. Obiekcje pojawiają się przy trzecim znaczeniu,

i uchwycenie związków logicznych między tymi zdaniami. Jak się wydaje, celem logiki formalnej jest to drugie, co bynajmniej nie ogranicza tego pierwszego zadania, stricte metafizycznego. Oczywiście jest niezwykle trudne powiązanie jednego z drugim; zadaniem logiki (i każdej „normalnej” nauki) jest swoiste upraszczanie (mające wyraz w tworzeniu modeli) rzeczywistości. Wydaje się, że i np. Arystotelesowsko-Tomaszowa koncepcja aktu i możności jest też takim tworzeniem modelu rzeczywistości, choć na takie twierdzenie przedstawiciele metafizyki tej zdecydowanie by protestowali (co widać z cytowanej wypowiedzi Kamińskiego i Zdybickiej).

16 Racją do takich sformułowań była dla Kamińskiego krytyka próby Salamuchy, któremu Kamiński zarzucał przekładanie na język logiki twierdzeń metafizyki.

17 S. Kamiński, Logika współczesna a filozofia, dz. cyt., 74. 
wyznaczonym przez aksjomat ekstensjonalności w teorii mnogości. Według Drewnowskiego zarzuty przeciw temu rodzajowi ekstensjonalności nie dotyczą KRL, jako że teoria mnogości sytuuje się poza logiką. Zarzut przeciw teorii mnogości jest ten, że w myśl aksjomatu „tożsame są każde dwie funkcje zdaniowe, które są prawdziwe dla tych samych przedmiotów. Jest to oczywiście ograniczenie rozważań tylko do zakresów argumentów funkcji z pominięciem wszelkich różnic w treści symboli funkcyjnych". Tak rozumiana ekstensjonalność jest czysto zakresowa i, zdaniem Drewnowskiego, „nie nadaje się nie tylko do żadnych subtelnych zastosowań filozoficznych, ale nawet do najprostszych opisów empirycznych"18. Odpowiadając na takie sformułowania Kamiński podkreślał, że „sprawa ekstensjonalności wyrażeń logiki ogranicza swobodę zastosowania tej logiki do dziedzin, w których obowiązuje ontologiczna teza ekstensjonalizmu. Metafizyka klasyczna wyraźnie zaś zakłada, że dwie równozakresowe cechy nie są ze sobą identyczne, np. transcendentalia: unum, verum, bonum"19. Dzisiaj owe spory nieco bledną wobec faktu np. bardzo

18 Tamże, 9. Ciekawe, że to ostatnie zdanie opiera Drewnowski na cytacie z pracy R. Barcan. Tymczasem tak naprawdę cytat z Marcus takiego stwierdzenia nie sugeruje, gdyż Marcus twierdzi, że ,jeśli będziemy utożsamiać logikę formalną z silnie ekstensjonalnym rachunkiem funkcyjnym (!), wtedy rację ma Strawson gdy głosi, że ,wyposażenie analityczne logika formalnego' jest nieadekwatne do rozbioru nawet najzwyklejszych typów zdań empirycznych" - zdanie to pochodzi ze wstępu do pracy M. Barcan, Modalities and intensional languages, Synthese 13(1961)4, w którym autorka pokazuje potrzebę rozszerzenia KRL o funktory intensjonalne.

19 Por. S. Kamiński, Co daje stosowanie, dz. cyt., 110. W tej kwestii w komentarzach z 10.02.1964 przesłanych Kamińskiemu Drewnowski słusznie wskazał, że „nie znam przypadku, by ekstensjonalność równoważnościowa lub tożsamościowa ograniczała możliwość oddawania odcieni treściowych na gruncie klasycznego rachunku logicznego" (właściwie, jak słusznie znów dodał Kamiński, w zastosowaniach logiki). Jak się wydaje, spór ten nie do końca jest zasadny. Jeśli popatrzymy na język klasycznej metafizyki, to opiera się on na klasycznym rachunku zdań, choć oczywiście niekoniecznie na węższym rachunku predykatów i powiązanej z nim przez aksjomat komprehenzji teorii mnogości. Co do przywołanych transcendentaliów: są one zakresowo równe, choć treściowo nietożsame, co jest oczywiste (nie tylko dla transcendentaliów). Oczywiście transcendentalia są 
szerokiego stosowania logik nieklasycznych $\mathrm{z}$ ich funktorami nieekstensjonalnymi. Tezy z tymi ostatnimi z kolei sprawdzają się np. w opierających się na KRL semantykach relacyjnych. Mamy więc funktory „treściowe”, które mogą być interpretowane ekstensjonalnie. Tu dochodzimy do następnej kwestii, a mianowicie

Ad e) Obu autorów łączy pogląd, że KRL nie wystarcza do uzasadnienia matematyki i musi być „uzupełniany pojęciami teoriomnogościowymi oraz badaniami metalogicznymi”. Drewnowski wskazywał, że metalogika, bazująca na aksjomatyce Zermelo-Fraenkla, nie nadaje się (ze względu na swe nieintuicyjne założenia) do stosowania poza matematyką, zaś metalogika nie nadaje się do zastosowań ze względu na aksjomat ekstensjonalności. Dlatego należy stosować metodę Hilberta-Ackermanna i „wystrzegać się nadbudowy metalogicznej”. Dyskusja ta znów pokazuje rzecz ciekawą u obu autorów, a mianowicie całkowite pomijanie logik nieklasycznych. Wygląda na to, że obaj dyskutanci, którzy wyrośli na gruncie silnie rozpowszechnionego w logice polskiej ekstensjonalizmu (to samo dotyczy np. Bocheńskiego), w zasadzie nie brali poważnie całego arsenału szeroko rozumianych logik modalnych ${ }^{20}$.

szczególne z innych względów, mianowicie z tego że stosują się analogicznie do każdego bytu (na zasadzie analogii transcendentalnej, a nie jednoznacznie).

20 Stanowisko to dobitnie wyraził „późny” Łukasiewicz, komentujący von Wrighta ujęcie modalności w następujących słowach: „gdy funkcje modalne będziemy uważać za funkcje intensjonalne, tj. za funkcje, których wartości prawdziwościowe nie zależą wyłącznie od wartości prawdziwościowych ich argumentów. Jak dotąd pozostaje dla mnie tajemnicą, co wówczas znaczyć by miały konieczność i możliwość". J. Łukasiewicz, Sylogistyka Arystotelesa z punktu widzenia współczesnej logiki formalnej, Warszawa 1988, 189. Pośrednio ten ekstensjonalizm ukazała też słynna praca J. Łosia, Logiki wielowartościowe a formalizacja funkcji intensjonalnych (Logiki wielowartościowe a formalizacja funkcji intensjonalnych, Kwartalnik Filozoficzny 17(1948)1-2.), której celem jest pokazanie, że funkcje intensjonalne w ogóle mogą być naukowo traktowane. 


\section{SWOISTOŚĆ METAFIZYKI}

Wreszcie mamy cały główny korpus dyskusji, a mianowicie kwestię podkreślanej przez Kamińskiego swoistości metafizyki, a w konsekwencji akcentowanej przez filozofów lubelskich niemożności aksjomatyzacji metafizyki i formalizacji (symbolizacji) jej twierdzeń. To właściwie sedno kontrowersji. Według Kamińskiego metafizyka jest nauką osobliwą, której osobliwość można streścić następująco ${ }^{21}$ : brak jest hierarchii tez w metafizyce; wprawdzie jej twierdzenia można ustawić w porządku od najwyższych praw bytu, przez twierdzenia o strukturze bytu, aż do szczegółowych twierdzeń o różnych bytach, ale te różnice są zbyt słabe, żeby uznać któreś z twierdzeń za bazowe na tyle, żeby w nich wirtualnie tkwiły inne twierdzenia (występuje przy tym problem sposobu ustalenia zbioru bazowych przesłanek); stąd dla Kamińskiego płynie wniosek, iż w metafizyce klasycznej brak jest związków wynikania logicznego między jej tezami, a jedynie występują zależności logiczno-treściowe.

Podstawą owej swoistości logicznej metafizyki jest fakt, iż uzasadnienie jej tez oparte jest na ontologicznej analizie bytu: „nowe tezy zawierają nie tylko wyszczególnienie treści tez wcześniejszych, lecz także jakieś nowe treści pochodzące $z$ nowych intelektualnych intuicji bytu w nowych aspektach, w nowych relacjach (nowe modi bytu). Mało, przy najbardziej dobranym układzie tez, wedle ich »ogólności« i »mocy«, zachodzi taka sytuacja, że dla poparcia słuszności pewnej tezy trzeba powołać się nie tylko na tezę wcześniejszą, ale właśnie na tezę późniejszą (...). Nie wiemy także, czy dadzą się sprowadzić do czysto formalnych »dowody z analogii«, korzystające z tego, iż między tezami zachodzi pewna odpowiedniość (...). Nie

21 Por. S. Kamiński, O ostatecznych przesłankach w klasycznej teorii bytu, w: S. Kamiński, M. Krąpiec, Z teorii i metodologii metafizyki, Lublin 1962, 319-331; artykuł jest przedrukiem z Roczników Filozoficznych 7(1959)1, 41-72, a więc jego treść była prawdopodobnie znana Drewnowskiemu w chwili pisania artykułu Czy możliwe jest stosowanie logiki symbolicznej w metafizyce? 
tylko faktycznie, lecz także i teoretycznie nie zachodzi więc czysta dedukcja tez. Może i dlatego przy próbach formalizowania dowodów z dziedziny metafizyki występuje tu dziwna potrzeba tak licznych i nieustannych w trakcie dowodzenia dodatkowych założeń"22. Innymi słowy, według Kamińskiego, tezy metafizyki są niezwykle bogate treściowo (w odróżnieniu od tez nauk formalnych). W rezultacie są one powiązane różnymi związkami treściowymi; wszystkie są formułowane na poziomie bardzo ogólnym, choć (przez intuitywny kontakt poznającego metafizyka $z$ bytem) w takim samym (analogicznym) stopniu dotyczą każdego indywiduum. Owa wielość powiązań uniemożliwia ścisłą hierarchizację tez (tak pod względem ogólności, jak i pod względem uzasadnienia). $Z$ tego też względu wynika następny sporny punkt dyskusji, a mianowicie kwestia możliwości aksjomatyzacji systemu metafizyki.

W świetle powyższych uwag metafizyka nie stanowi systemu dedukcyjnego w zwykłym znaczeniu. Jak wskazuje Kamiński, metafizyka stanowi właściwie zbiór tez, z których wszystkie w pewnym stopniu są principiami, choć kolejność w ich uzasadnianiu nie jest całkiem dowolna. „Podział na aksjomaty i twierdzenia nie stosuje się do ogólnej metafizyki. Czy wobec tego odnosi się do niej zarzut, że nie jest systemem uzasadnionych twierdzeń, a co za tym idzie, wiedzą o charakterze naukowym. Nie! Ona w swoisty sposób uzasadnia swoje pryncypia”. Tu, jak zauważa Kamiński, można postawić zarzut, jak nauka może uzasadniać swoje pryncypia? Jest to paradoks pozorny - „metafizyka nie uzasadnia pośrednio przesłanek naczelnych dla twierdzeń pochodnych metafizyki. Jest zbiorem pryncypiów uzasadnionych bezpośrednio, popartych racjami elenktycznymi oraz w pewien sposób wzajemnie dowodowo powiązanych" 23 . To ważne sformułowania Kamińskiego. Jak widać, podkreśla on rolę

22 Tamże, 323-324.

23 Por. S. Kamiński, O ostatecznych przesłankach, dz. cyt., 325. 
uzasadnienia bezpośredniego na każdym etapie pracy metafizyka ${ }^{24}$. To wymaganie intuitywnego kontaktu z bytem (rzeczywistością) sprawia, że właściwie trudno mówić o systemie metafizyki jako wytworze poznania metafizycznego pojętego czynnościowo. Jak się wydaje, trzeba by mówić o poznaniu metafizycznym, w którym nie da się oderwać jego wytworów od czynności. W tym sensie jest to źródło całkowitej specyfiki metafizyki, jako wiedzy specyficznej.

Tymczasem Drewnowski spostrzegał metafizykę jako teorię naukową, czyli jako zbiór twierdzeń powiązanych logicznie i treściowo. „Podobnie ma się sprawa z każdą inną dziedziną nauk o rzeczywistości. Zasadnicze tezy są tam bądź uogólnieniami, dotyczącymi swoistych stosunków rzeczywistych, bądź są zdaniami o konkretnych faktach. Wiążą się więc też nie tylko na podstawie formy. Gdyby więc słuszne było, że $z$ tych powodów »aksjomatyczny system nie może stanowić nawet jakby siatki dla systemu metafizyki«, to również nie mógłby stanowić tego dla żadnej nauki o rzeczywistości. (...) To zresztą przeczyłoby faktom, gdyż istnieje wiele prób tworzenia aksjomatycznej »siatki« dla nauk o rzeczywistości. Każda bowiem teoria naukowa daje się sformalizować. Dla każdego można tworzyć "siatkę" aksjomatyczną przez dołączenie nowych aksjomatów do klasycznego rachunku logicznego"25. Przeciw takiej możliwości

24 Stanowisko Kamińskiego w tej mierze nie było zbyt spójne. Z powyższymi uwagami kłóci się bowiem np. następująca konstatacja: „metafizyka jako teoria zakłada jakiś system dedukcyjny, który przenika jej budowę. Metodologia nauk empirycznych i teorie argumentacji nieformalnych pomogą uprawomocnić metodologicznie sposoby postępowania stosowane w klasycznej filozofii bytu". S. Kamiński Logika współczesna a filozofia, dz. cyt., 80. Jeśli faktycznie jest za metafizyką jakiś system dedukcyjny, to powinien istnieć jakiś mocny związek między tezami metafizyki paralelny do związków w zakładanym systemie dedukcyjnym.

25 Por. J.F. Drewnowski, Czy możliwe jest stosowanie logiki symbolicznej w metafizyce?, dz. cyt., 18-19. Zdaje się, że źródłem ich [tzn. posądzeń, że Salamucha i inni chcą ograniczyć się jedynie do logiki zdań i logiki nazw, a więc, że chcą „zubożyć” metafizykę i „zdeformować” ją - M.L.] jest pogląd jakoby nie można było w ogóle stworzyć poprawnej symboliki wyrażającej owe kilkakrotnie wymieniane: „złożenia wewnętrzne bytu jako bytu”, „wewnętrzne złożenia bytowe”, „wewnętrzną strukturę bytu”, „składniki metafizyczne bytu” 
Kamiński wysuwał argument opierający się na twierdzeniach limitacyjnych $^{26}$. Drewnowski odpierał te zarzuty wskazując, iż „osiągnięte tu wyniki wcale nie przeczą samej możliwości dowolnie daleko posuniętej formalizacji tych teorii. Przeciwnie - dopiero gdy teoria jest zaksjomatyzowana, można pytać o jej zupełność, rozstrzygalność itd. Jak wiadomo, arytmetyka już jest nierozstrzygalna, ale chyba wystarczyłoby, gdyby metafizyka dała się tak zaksjomatyzować jak arytmetyka"27. Trudno się oczywiście zgodzić z tą ostatnią konstatacją (tu Kamiński miał rację, co do konsekwencji twierdzenia Gödla), choć oczywiście intencja Drewnowskiego zdaje się być jasna. Jest nią postulat możliwie szerokiego sformalizowania (symbolizowania) zarówno systemu metafizyki, jak i całej nauki. Swoją drogą ciekawe jest odwołanie się Kamińskiego do twierdzeń limitacyjnych w odniesieniu do formalizacji metafizyki; choć oczywiście pełna aksjomatyzacja systemu nie jest możliwa (przy założeniu jego niesprzeczności), to jednak nie wiadomo dlaczego mamy nie podejmować prób formalnej

itp. Zdaje się, że nie opublikowano dotąd zadowalającej próby symbolicznego sformułowania tych pojęć. Ale też dotychczas nie podano nigdzie dowodu, że sformułowanie takie jest niemożliwe. Jednak za taką możliwością przemawiałyby nieograniczone możliwości formalne, jakie otwiera wprowadzanie nowych symboli stałych do klasycznego rachunku logicznego. Nie ma tu bowiem żadnych ograniczeń ani co do ich treści, ani co do treści ich argumentów, ani co do liczby tych argumentów". J.F. Drewnowski, Stosowanie logiki symbolicznej w filozofii, dz. cyt., 62.

26 „Warto podkreślić, że od pewnego czasu dążenie do aksjomatyzacji poważnie zmalało. Skolem (1922-1933), Gödel (1931), Tarski (1931) i Church (1936) udowodnili szereg twierdzeń ograniczających zasadniczo tak logistyczny, jak również formalistyczny wykład matematyki. Okazało się bowiem, że np. już ogół prawd arytmetycznych nie da się ująć w ścisły system dedukcyjny. Warto również przypomnieć słowa Posta, że »nieunikniony jest przynajmniej częściowy odwrót od całego aksjomatycznego prądu z końca XIX i początku XX wieku oraz powrót do pojęć znaczenia i prawdy będących istotą matematyki« oraz wypowiedź Mostowskiego, że »stoimy w obliczu załamania się przedsięwziętej na wielką skalę próby rozwiązania odwiecznego zagadnienia prawdy za pomocą sformalizowanych teorii logicznych i matematycznych «. Bardziej chyba dotyczy to nauk nieformalnych, a zwłaszcza o tak swoistej aparaturze pojęciowej, jaką ma metafizyka »klasyczna«". S. Kamiński, Co daje stosowanie logiki symbolicznej w metafizyce?, dz. cyt., 112.

27 J.F. Drewnowski, Stosowanie logiki symbolicznej w filozofii, dz. cyt., s. 64. 
analizy fragmentów systemu metafizyki (czy jakiejś innej dziedziny)? To pytanie prowadzi nas do ostatniej kwestii spornej, która, jak się wydaje, jest naczelnym motywem stojącym za wystąpieniem Drewnowskiego, tzn. sprawy wartości poznawczej formalizacji dowodu ex motu dokonanej przez J. Salamuchę.

Kamiński przedstawił szereg krytycznych uwag pod adresem formalizacji dowodu ex motu ${ }^{28}$. Według niego (1) celem pracy Salamuchy jest „transponująca rekonstrukcja twierdzeń i dowodów św. Tomasza w języku możliwie zbliżonym do logicznego (...) Dokładniej charakteryzując, operacja ta przebiega w następujący sposób. Po ustaleniu: symboli stałych dla swoistych pojęć danego fragmentu metafizyki formułuje się symbolicznie te tezy, które służyć będą jako przesłanki w dowodach. Nie jest to jednak jedynie symbolizacja. Do tego sformułowania bowiem używa się obok stałych specyficznych, zmiennych przebiegających przez opisane rodzaje przedmiotów oraz stałych logicznych. Te specyficzne przesłanki dołącza się do klasycznego rachunku logicznego i używając jego reguł, wyprowadza się nowe tezy metafizyki. Przesłanki metafizyczne muszą na tyle scharakteryzować stałe specyficzne w nich występujące, na ile jest to potrzebne $\mathrm{w}$ dowodach danego fragmentu metafizyki (ale niekoniecznie muszą być układem zupełnym definicji przez postulaty dla tych terminów). Praktycznie jest to o tyle ułatwione, że w samych dowodach stałe specyficzne często nie odgrywają jako takie istotnej roli; traktowane są jako zmienne. Nie zawsze bowiem symbole pozalogiczne dadzą się zdeterminować na tyle, aby ich treść można było w pełni wykorzystać $w$ formalnych operacjach dowodowych" 29 . Inne zarzuty Kamińskiego dotyczą: (2) poprawności formalnej dowodu -

28 Por. J. Salamucha, Dowód ex motu na istnienie Boga. Analiza logiczna argumentacji św. Tomasza z Akwinu, Collectanea Theologica 15(1934)1-2, t. 54, 53-92, przedruk w: Tenże, Wiedza i wiara. Wybrane pisma filozoficzne, red. J. Jadacki, K. Świętorzecka, Lublin 1997, $333-364$.

29 S. Kamiński, Co daje stosowanie logiki symbolicznej w metafizyce?, Roczniki Filozoficzne 12(1964)1, 108. 
(Salamucha ma dokonywać podstawiania stałych pozalogicznych za zmienne w tezach logiki i w związku z tym w dowodzie winna być dołączana przesłanka egzystencjalna, stanowiąca warunek istnienia i jedyności obiektów denotowanych przez owe stałe); inny zarzut dotyczy różnego, zdaniem Kamińskiego, zakresu zmienności zmiennych w poszczególnych przesłankach ${ }^{30}$, (3) przyjęcia przesłanek pozasystemowych czy (4) wyrażania istnienia za pomocą kwantyfikatora szczegółowego ${ }^{31}$. We wcześniejszej pracy Logika a filozofia, do której bezpośrednio odnosi się Drewnowski w analizowanym maszynopisie, poza zarzutem o „transponującej rekonstrukcji” mamy inny, który stanowi, że (5) „bezpośrednie stosowanie czystej logiki do teorii bytu, dla zamiany jej w naukę dedukcyjną powoduje, iż taki system filozofii staje się hipotetyczno-dedukcyjny, albo po prostu układem tautologii ze względu na określony język" 32 .

Reakcja Drewnowskiego na te zarzuty jest dość ostra. Drewnowski podkreśla, że „praca Salamuchy stanowi logiczną analizę dowodu ex motu (...) oprócz zwykłych symboli teorii dedukcji i kwantyfikatorów autor wymienia też pojęcia teorii stosunków i teorii mnogości, jednakże nie opiera się na żadnym swoistym aksjomacie teorii mnogości (...) w całej pracy stosuje się tylko klasyczny rachunek logiczny" - środki więc stosowane przez Salamuchę są bezpieczne są to pojęcia klasycznego rachunku logicznego (i jak się wydaje)

30 Tamże, 109: „Zmienna x w pierwszej przesłance (zasadzie ruchu), choć związana jest kwantyfikatorem ogólnym, dotyczy tylko bytów przygodnych, a zmienna t, którą wiąże kwantyfikator szczegółowy, dotyczy zarówno bytów przygodnych, jak i bytu koniecznego, czyli Boga. Nie można tu tłumaczyć się tym, że funktory odpowiednio determinują zakres zmienności zmiennych jednostkowonazwowych, bo nie zawsze funktory od tych zmiennych są traktowane treściowo. Potrzeba więc dokładniejszej determinacji cząstkowego zakresu zmienności. Czy to nie wymaga już posłużenia się jakąś teorią typów zbiorów względnie przyjęcia układu aksjomatów determinujących zakres zmienności? W takim przypadku do przeprowadzania dowodów metafizycznych nie wystarczyłby klasyczny rachunek logiczny". Trudno znaleźć poparcie dla tych zarzutów w tekście Salamuchy.

31 S. Kamiński, Co daje stosowanie logiki symbolicznej w metafizyce?, dz. cyt., 109.

32 S. Kamiński, Logika współczesna a filozofia, 75. 
niespecyficznie użyte pojęcia teorii mnogości. Oczywiście użyty jest rachunek predykatów, co z góry powoduje użycie kwantyfikatora szczegółowego w funkcji egzystencjalnej, co faktycznie można potraktować jako mankament próby Salamuchy ${ }^{33}$. Co do innych uwag Kamińskiego: (1) sam opis próby Salamuchy wydaje się adekwatny. Jak zauważa Drewnowski, choć sam okres warunkowy, którego następnik jest tezą o istnieniu Poruszyciela, jest tautologią, „wystarczy okazać prawdziwość każdego z trzech czynników poprzednika. Reszta pracy podaje rekonstrukcję symboliczną rozumowań św. Tomasza, w których dowodzi on prawdziwości tych trzech czynników poprzednika okresu warunkowego. Te szczegółowe dowody nie dają się sprowadzić do tautologii logicznych (...) lecz wymagają oparcia się na przesłankach metafizycznych (...) symboliczne sformułowania tych przesłanek dołącza się jako nowe aksjomaty"34. Stanowisko Drewnowskiego nie różni się więc jakoś zasadniczo od opisu podanego przez Kamińskiego. Z kolei zarzut (2), o wątpliwej poprawności formalnej dowodu Salamuchy, trzeba by odnieść do dyskusji, czy taka transponująca rekonstrukcja opiera się na podstawianiu czy raczej, jakby chciał Ajdukiewicz, na interpretacji tez logiki w języku pozalogicznym. Mamy tu zatem raczej zastosowania tez logiki niż same operacje na tezach logiki. Nie wiadomo dlaczego trzeba by dołączać w dowodzie warunek istnienia i jedyności. Nie wiadomo też dlaczego przyjęcie „przesłanek pozasystemowych” miałoby być wadą roboty Salamuchy; zdaje się raczej zaletą próby, że ujawnia ona ukryte czy domyślne założenia, które trzeba przyjąć, aby zachować poprawność dowodu Tomaszowego. Pozostaje jeszcze zarzut (5), według którego

33 Przy czym Kamiński pomija dywagacje Salamuchy na temat kwantyfikatora szczegółowego; Salamucha wskazuje, że użycie tego kwantyfikatora „tak się mieni znaczeniowo, jak mieni się samo pojęcie istnienia; dopiero kontekst dokładnie precyzuje, o jakie istnienie dokładnie chodzi". J. Salamucha, Dowód ex motu na istnienie Boga. Analiza logiczna argumentacji św. Tomasza z Akwinu, dz. cyt., 337.

34 Por. J.F. Drewnowski, Czy możliwe jest stosowanie logiki symbolicznej w metafizyce?, dz. cyt., 16. 
metafizyka po zastosowaniu do niej narzędzi logiki traci swój apodyktyczny charakter i staje się systemem tautologii ze względu na dany język. Jak się wydaje, każdy układ tez można potraktować jako zbiór postulatów znaczeniowych dla terminów w nich zawartych i sytuacja metafizyki nie jest tu inna. U podstaw uwag Kamińskiego leży, jak należy sądzić, to, że, jak pisze Drewnowski, „przynajmniej jakieś przesłanki dowodów metafizycznych nie dają się udowodnić $\mathrm{w}$ ramach takiego ewentualnego systemu dedukcyjnego, lecz muszą być przyjęte przez odwołanie się do 'intelektualnej oczywistości ${ }^{35}$ przedmiotowej' Takie wymaganie jest oczywiste w każdej dziedzinie wiedzy. (...) Te uzgodnione punkty wyjścia formułujemy w postaci założeń swoistych dla danej dziedziny”. Jak się wydaje niepokój Kamińskiego opiera się na nieporozumieniu: celem zabiegów formalizacyjnych logików nie jest tu stworzenie nowej metafizyki formalnej, ale raczej, jak to pisze Drewnowski, „ks. Salamucha formułuje to, co wystarcza do nadania rozumowaniu św. Tomasza poprawnej logicznie postaci"36.

\section{HORROR LOGISTICUS}

Próbując znaleźć racje dla tak surowego sądu Kamińskiego wobec prób Salamuchy, jakby sztandarowego osiągnięcia Koła Krakowskiego zmierzającego do wykazania, że myśl katolicka jest racjonalna i może korzystać z najnowszych narzędzi logiki sięgnijmy do manifestu Eukasiewicza z $W$ obronie logistyki. „W ten sposób staramy się wszystkie wywody logiczne sformalizować, to znaczy ująć je w napisy tak skonstruowane, by można skontrolować poprawność wywodu, nie odwołując się do znaczeń tych napisów. Znaczeń bowiem uchwycić nie umiemy, znaki zaś są widoczne i wyraźne, i porównując je z sobą

35 Por. tamże, 61.

36 Tamże, 61. 
możemy się oprzeć na oczywistości wzrokowej"37. Trzeba stwierdzić, że jednym z motywów antylogistycznego stanowiska filozofów szkoły lubelskiej był lęk przed dążeniami logików do ujednoznacznienia wszelkiego dyskursu filozoficznego i mechanizacji rozumowań w obrębie klasycznego rachunku logicznego ${ }^{38}$. Jest to ciekawe, bo Kamiński, przynajmniej w pierwszym, tzw. formalnym okresie pracy naukowej podejmował próby z logiki formalnej i, jak się wydaje, zdawał sobie dobrze sprawę z zadań i możliwości logiki formalnej jako dziedziny, której przedmiotem są rachunki logiczne ${ }^{39}$. Ogólne wnioski Kamińskiego z próby Salamuchy zadziwiają jeszcze z tego względu, że próba formalizacji dotyczy wszak dowodu ex motu, czyli fragmentu filozofii Boga, z jej swoistym charakterem, polegającym na wyprowadzaniu konsekwencji systemowych metafizyki ogólnej (wszak pojęcie absolutu pojawia się w punkcie dojścia, anie punkcie wyjścia metafizyki). Tymczasem prace Kamińskiego zdają się być obroną całej metafizyki ogólnej ${ }^{40}$. Tego jak się zdaje nie mógł pojąć

37 Por. J. Łukasiewicz, W obronie logistyki (w: Myśl katolicka wobec logiki współczesnej), Studia Gnesnensia 15(1937), 16-17.

38 Taki niepokój może budzić wstęp do pracy Salamuchy, gdzie pisze on, iż „Logika matematyczna, chociaż historycznie jeszcze tak młoda, dostarcza nam wielu nowych, subtelnych narzędzi ścisłego myślenia. (...) Stanowisko przesadnie konserwatywne na temat logiki jest szczególnie groźne dla pracy filozoficznej (...) badając poprawność dowodów Arystotelesa czy św. Tomasza z Akwinu nie umiałem wtłoczyć ich w formy sylogistyczne".

39 Warto tu przypomnieć oryginalne próby interpretacji teorii zdań kategorycznych w języku klasycznego rachunku zdań; por. S. Kamiński, Tradycyjna teoria wnioskowania bezpośredniego jako pewien fragment dwuwartościowego rachunku zdań, Studia Logica 11(1961), 7-22.

40 Kiczuk w bardzo wyważony sposób podsumował dyskusję autorów lubelskich z Drewnowskim w sprawie próby Salamuchy: „Faktycznie, Salamucha najważniejszych przesłanek nie uzasadnił, ale przyjął je jako założenia. Autorzy mieli też rację mówiąc, że twierdzenie, iż dowód na istnienie Boga nie jest dowodem formalnym, ściśle dedukcyjnym, nie jest równoznaczne z twierdzeniem, że nie jest dowodem naukowym. Tezę o rzekomo nienaukowym charakterze dowodu na istnienie Boga sugerował Drewnowski. Zarysowane analizy świadczą, że obawy Drewnowskiego były bezpodstawne. Szkoda tylko, że przedstawiciele szkoły lubelskiej w swych publikacjach nie używali zwrotów „bezpośrednie uzasadnianie 
Drewnowski, który próbował konsekwentnie analizować samą formalizację argumentu ex motu.

Wracając do stosowalności logiki, być może, jak zasugerował w dyskusji Majdański, działalność szkoły w zakresie logiki traktowana była zasadniczo jako rodzaj ćwiczeń intelektualnych jej członków, natomiast przekonanie o niemożliwości owocnego podejścia do stosowania logiki formalnej w uprawianiu filozofii było dominujące. Podobne stanowisko (nieco łagodniej) sformułował J. Herbut, który przypisywał charakter warsztatowy samemu ,eksperymentowi” Salamuchy: „eksperymentowi, bo logiczną rekonstrukcję dowodu ex motu uważał on za próbę warsztatową" ${ }^{11}$. Takie podejście szkoły (w sumie powiązane jednak à rebours z drogą proponowaną przez Salamuchę) stało w silnej opozycji do kierunku, który podyktował Bocheński, proponujący filozofię jako analizę logiczną. Podejście Bocheńskiego, znowu, przynajmniej programowo, nadmiernie akcentujące rolę logiki w analizie (streszczające się w sloganie „poza logiką jest tylko absurd") okazało się prekursorskie i niezwykle owocne w uprawianiu filozofii „skromnej” - analizy pojęciowej, którą z kolei można nazwać prekursorką współczesnych ontologii stosowanych ${ }^{42}$. Oczywiście, co warto tu podkreślić, według Bocheńskiego, w stosowaniu logiki poza logiką najważniejsza jest logika jako narzędzie analizy pojęć,

twierdzeń” i „pośrednie uzasadnianie twierdzeń”. Zob. S. Kiczuk, Spór o stosowalność logiki formalnej do filozofii w szkole lubelskiej, Roczniki Filozoficzne 44(1996)1, 14.

41 Por. J. Herbut, O metodologicznym unowocześnianiu teistycznej metafizyki. Refleksje nad poczynaniami ks. Jana Salamuchy, Zeszyty Naukowe KUL 23(1980)1, 21-32 (cyt. s. 31). Herbut dalej zauważa, że korzyścią z próby Salamuchy było to, że „metafizycy sprowokowani do dyskusji tym eksperymentem, podając racje niesprowadzalności ich języka do języka logiki, dokładniej zdali sobie sprawę z natury własnych operacji tworzenia pojęć, formowania zdań i ich uzasadniania”; zagadnienie stosowania logiki do metafizyki przedstawia na szerszym tle K. Wolsza w pracy Teodycea sformalizowana, w: Filozofia Boga, t. 2, red. S. Janeczek, A. Starościc, Wydawnictwo KUL, Lublin 2017, 195-218.

42 Por. prace Bocheńskiego zebrane np. w tomie J. Bocheński, Logika a filozofia, Warszawa 1993; na temat metody analizy por. M. Lechniak, J.M. Bocheński's method of philosophical analysis and contemporary applied ontology, Studies in East European Thought 65(2013)1-2, 17-26. 
a nie - narzędzie umożliwiające wyrafinowane formalnie inferencje. Te, według Bocheńskiego, są raczej skromne (albo dają się sprowadzić do skromnych) i cała formalna maszyneria wypracowana np. przez logikę zdań jest zasadniczo dla filozofa nieprzydatna. analiza wyrafinowanych. Tak rozumiana logika (sięgająca wszak pełną garścią do narzędzi formalnych) winna być stosowana w analizie języka metafizyki: „zdaje się, że pozwoli to [analiza języka filozofii bytu ML] rozwiązać niejedną zagadkę tego trudnego języka i uczynić go mimo całej jego specyficzności bardziej zrozumiałym oraz naukowo uprawomocnionym"43.

\section{BIBLIOGRAFIA}

Adamczyk M., Wiedza - wiara - racjonalność. Jana Franciszka Drewnowskiego program logizujacej modernizacji myśli fllozoficzno-teologicznej, TN KUL, Lublin 2015.

Bocheński J. M., Co logika data filozofi??, Studia Filozoficzne (1988)6-7, 7-14.

Bocheński J. M., Logika i filozofia. Wybór pism, PWN, Warszawa 1993.

Drewnowski J. F., Czy możliwe jest stosowanie logiki symbolicznej w metafizyce?, mps (1963); Listy do S. Kamińskiego z listopada 1962 i z lutego 1964.

Drewnowski J. F., Filozofia i precyzja. Zarys programu filozoficznego i inne pisma, red. S. Majdański, S. Zalewski, Lublin 1996.

Drewnowski J. F., Stosowanie logiki symbolicznej w flozofii, Studia Philosophiae Christianae 1(1965)1-2, 53-65.

Drewnowski J. F., Uwagi w zwiqzku z artykutem dyskusyjnym ks. Kamińskiego is. Zofii Zdybickiejpt. Osposobie poznania Boga, Znak 17(1965)128-129, 346-355; przedruk w: J.F. Drewnowski, Filozofia i precyzja, s. 224-233.

Herbut J., O metodologicznym unowoczésnianiu teistycznej metafizyki. Refleksje nad poczynaniami ks. Jana Salamuchy, Zeszyty Naukowe KUL 23(1980)1, 21-32.

Kamiński S., Co daje stosowanie logiki formalnej do metafizyki klasycznej?, Roczniki Filozoficzne 12(1964)1, 107-112.

Kamiński S., Logika wspótczesna a fllozofia, Roczniki Filozoficzne 9(1961)1, 49-84.

Kamiński S., O ostatecznych przestankach w klasycznej fllozofii bytu, Roczniki Filozoficzne 7(1959)1, 41-72.

43 Por. S. Kamiński, Logika współczesna, art. cyt., 78. 
Kamiński S., O zastosowaniach logiki wspótczesnej do metafizyki klasycznej, w: Kamiński S., Krąpiec M. A., Z teorii i metodologii metafizyki, Lublin 1962, 273-294.

Kamiński S, Zdybicka Z. J., W odpowiedzi na uwagi Jana Fr. Drewnowskiego, Znak (1965)2-3, 355-365.

Kiczuk S., Spór o stosowalnośćlogiki formalnej do filozofii w szkole lubelskiej, Roczniki Filozoficzne 44(1996)1, 5-19.

Lechniak M., J.M. Bocheński's method of philosophical analysis and contemporary applied ontology Studies in East European Thought 65(2013)1-2, 17-26.

Łoś J., Logiki wielowartościowe a formalizacja funkcji intensjonalnych, Kwartalnik Filozoficzny 17(1948)1-2.

Łukasiewicz J., Sylogistyka Arystotelesa z punktu widzenia wspótczesnej logiki formalnej, PWN Warszawa 1988.

Łukasiewicz J., W obronie logistyki (w: Myśl katolicka wobec logiki wspótczesnej), Studia Gnesnensia 15(1937), 12-26; 159-165.

Wolak Z., Neotomizm a Szkota Lwowsko-Warszawska, Ośrodek Badań Interdyscyplinarnych, Kraków 1993.

Wolsza K., Teodycea sformalizowana, w: Filozofia Boga, t. 2, red. S. Janeczek, A. Starościc, Wydawnictwo KUL, Lublin 2017, 195-218.

\title{
APPLYING LOGIC IN PHILOSOPHY. THE DEBATE BETWEEN STANISŁAW KAMIŃSKI AND JAN F. DREWNOWSKI
}

\begin{abstract}
This paper considers and assesses the discussion between J. F. Drewnowski and S. Kamiński concerning how to apply logic in philosophy (more precisely: in general metaphysics within the Aristotelian-Thomistic tradition). In this debate, Drewnowski defended the position of the Krakow Circle according to which it is possible to apply the tools of formal logic in metaphysics. In opposition to Drewnowski, Kamiński formulated many arguments for the thesis that it is impossible to apply formal logic in philosophy. The second half of this paper draws some conclusions from this debate that are relevant to our current understanding of the application of logic in philosophy. $\mathrm{n}$ the final part of the paper we criticize Kamiński's view, which is characteristic of the so-called Lublin philosophical school.
\end{abstract}

Keywords: applicability of logic, Thomistic metaphysics, system of classical metaphysics, formalization of Aquinas' proof ex motu

\footnotetext{
MAREK LECHNIAK

lechmar@kul.pl

Katolicki Uniwersytet Lubelski Jana Pawła II, Instytut Filozofii

al. Racławickie 14, 20-950 Lublin
}

DOI: 10.21697/spch.2019.55.2.03 